\title{
Surgical techniques of phalloplasty in transgender patients: a systematic review
}

\author{
Daniel Boczar ${ }^{1}$, Maria T. Huayllani ${ }^{1} \wedge$, Humza Y. Saleem ${ }^{2}$, Gabriela Cinotto ${ }^{1}$, Francisco R. Avila ${ }^{1}$, \\ Salam Kassis ${ }^{3}$, Xiaona Lu ${ }^{4}$, Brian D. Rinker ${ }^{1}$, Antonio J. Forte ${ }^{1 \wedge}$ \\ ${ }^{1}$ Division of Plastic Surgery, Mayo Clinic, Jacksonville, FL, USA; ${ }^{2}$ Department of Surgery, Mayo Clinic, Jacksonville, FL, USA; ${ }^{3}$ Department \\ of Plastic Surgery, Vanderbilt University Medical Center, Nashville, TN, USA; ${ }^{4}$ Division of Plastic and Reconstructive Surgery, Yale School of \\ Medicine, New Haven, CT, USA \\ Contributions: (I) Conception and design: AJ Forte, MT Huayllani, D Boczar; (II) Administrative support: AJ Forte, BD Rinker; (III) Provision \\ of study materials or patients: None; (IV) Collection and assembly of data: MT Huayllani, D Boczar, G Cinotto, FR Avila; (V) Data analysis and \\ interpretation: MT Huayllani, X Lu, BD Rinker, FR Avila; (VI) Manuscript writing: All authors; (VII) Final approval of manuscript: All authors. \\ Correspondence to: Antonio J. Forte, MD, PhD. Mayo Clinic Florida, 4500 San Pablo Road, Jacksonville, Florida 32224 USA. \\ Email: ajvforte@yahoo.com.br.
}

\begin{abstract}
Gender confirmation surgery has a crucial role among transgender individuals. Phalloplasty is a procedure that uses flaps for phallic shaft creation. Flaps can be classified in free flaps or pedicle flaps and can be obtained from different donor sites such as forearm, thigh, abdomen, groin, and leg, and upper back. We conducted a systematic review about surgical flaps for phallic shaft creation in transgender patients. A systematic review was conducted on PubMed/MEDLINE, Cochrane Clinical Answers, and Cochrane Central Register of Controlled Trials databases without timeframe limitations. Exclusion criteria included articles that reported phalloplasty on patients other than transgender, as well as other surgical techniques such as urethroplasty, vaginectomy, hysterectomy and studies focused on psychosocial outcomes. Two hundred twenty-eight potential articles were identified in the initial search. Forty-one studies fulfilled the inclusion and exclusion criteria. Surgical flaps for phallic shaft creation in transgender patients were reported on 1,391 cases. Microsurgical flaps were the most common (24 of 33). The flap technique most frequently described was radial forearm flap (15 of 33) followed by Anterolateral thigh flap (7 of 33), Latissimus dorsi flap ( 5 of 33), abdominal flap (4 of 33), fibular flap ( 3 of 33), and groin flaps (3 of 33). The literature on surgical flaps for phallic shaft creation in transgender patients reflected how challenging the reconstruction of the phallus is. In summary, there is no universal choice of flap that could be applied to every patient. Therefore, the surgical approach must be chosen considering surgeon experience, physical examination, and patient desire. We hope this review supports future studies on surgical flaps for phallic shaft creation in transgender patients.
\end{abstract}

Keywords: Sex reassignment surgery; surgical flaps; transsexualism

Submitted May 06, 2020. Accepted for publication Nov 09, 2020.

doi: 10.21037/atm-20-3527

View this article at: http://dx.doi.org/10.21037/atm-20-3527

^ ORCID: Maria T. Huayllani, 0000-0003-2690-1635; Antonio J. Forte, 0000-0003-2004-7538. 


\section{Introduction}

Gender confirmation surgery has a crucial role amongst transgender individuals, especially since this population is at risk for psychological and physical sequels $(1,2)$. The complexity of the penis, in terms of its anatomy and function make phalloplasty a challenging reconstruction that requires a multidisciplinary approach (3). The ideal phallic reconstruction should address capacity to void while standing, sensation (tactile and erogenous), sexual satisfaction, low morbidity for both receptor and donor sites, and an aesthetic phallus (4).

The modern phalloplasty surgery started in 1945 , with a report of a female-to-male phalloplasty conducted by Sir. Harold Gilles, that took thirteen stages during four years (1). Although numerous surgical techniques have been reported after that, design of a complete functional phallus is still pending. In clinical practice, phalloplasty approach has been chosen taking into consideration multiple factors such as surgeon experience, patient body habitus, and patient desire (1). All techniques demonstrate some degree of morbidity and absence of long-term efficacy $(5,6)$. Complications such as fistulae and strictures are prevalent, but patient satisfaction is reported to be high $(1,7)$.

Flap-based approach for phalloplasty seems to be the best option for gender reassignment surgery. These can be classified into free flaps and pedicle flaps and can be obtained from different donor sites such as forearm, tight, abdomen, groin, and leg. We believe that a summary of publications on flap-based phalloplasty can support future studies on the field. Therefore, we conducted a systematic review about surgical flaps for phallic shaft creation in transgender patients. We present the following article in accordance with the PRISMA reporting checklist (available at http://dx.doi.org/10.21037/atm-20-3527).

\section{Methods}

\section{Search strategy}

On November 1st of 2019, two reviewers (DB, MTH) conducted independent searches of the PubMed/ MEDLINE, Cochrane Clinical Answers, and Cochrane Central Register of Controlled Trials databases, without time frame limitations. Disagreements regarding article identification and final selection for inclusion of the literature were resolved by another reviewer (AJF). Search was done using the follow key words: Phalloplasty; Penis shaft creation; Flap. The bibliographies of the studies that fulfilled the study eligibility criteria were also examined, looking for articles not present in our initial search. This study followed the guidelines outlined in the Preferred Reporting Items for Systematic reviews and Meta-Analyses (PRISMA).

\section{Selection criteria}

Eligibility criteria included articles reporting surgical flaps for phallic shaft creation in transgender patients. Thus, we excluded articles that reported phalloplasty in non-transgender patients, and those that reported other surgical techniques such as urethroplasty, vaginectomy, hysterectomy, erectile device, aesthetic refinements, and procedures to treat complications of phalloplasty. We also excluded studies focused on psychosocial outcomes. Abstracts, presentations, reviews, meta-analyses, and nonEnglish literature were also excluded.

\section{Data extraction, processing, and statistical analysis}

Extracted data included the year of the publication, country, number of cases, flap type and name. Data extraction from articles, tables, and figures was performed by two reviewers (DB, MTH), with the accuracy of data entry confirmed by an additional reviewer (AJF). Descriptive statistics were used to describe number of patients and flap type.

\section{Results}

Two hundred twenty-eight potential articles were found in the literature on initial search. Of those 33 studies fulfilled the inclusion and exclusion criteria (Figure 1, Table 1). Surgical flaps for phallic shaft creation in transgender patients were reported on 1,391 cases. Authors from different parts of the world shed light on the topic: Europe (20 of 33), Asia (7 of 33), North America (5 of 33), and Middle East (1 of 33). Most of the articles (29 of 33) reported only one type of surgical technique. Four articles reported outcome comparison of different techniques. Twenty-four authors reported microsurgical flaps and 13 authors reported pedicled flaps. The flap technique most frequently described was radial forearm flap (15 of 33) followed by anterolateral thigh flap (7 of 33), latissimus dorsi flap (5 of 33), abdominal flap (4 of 33), fibular flap (3 of 33 ), and groin flap (3 of 33). 

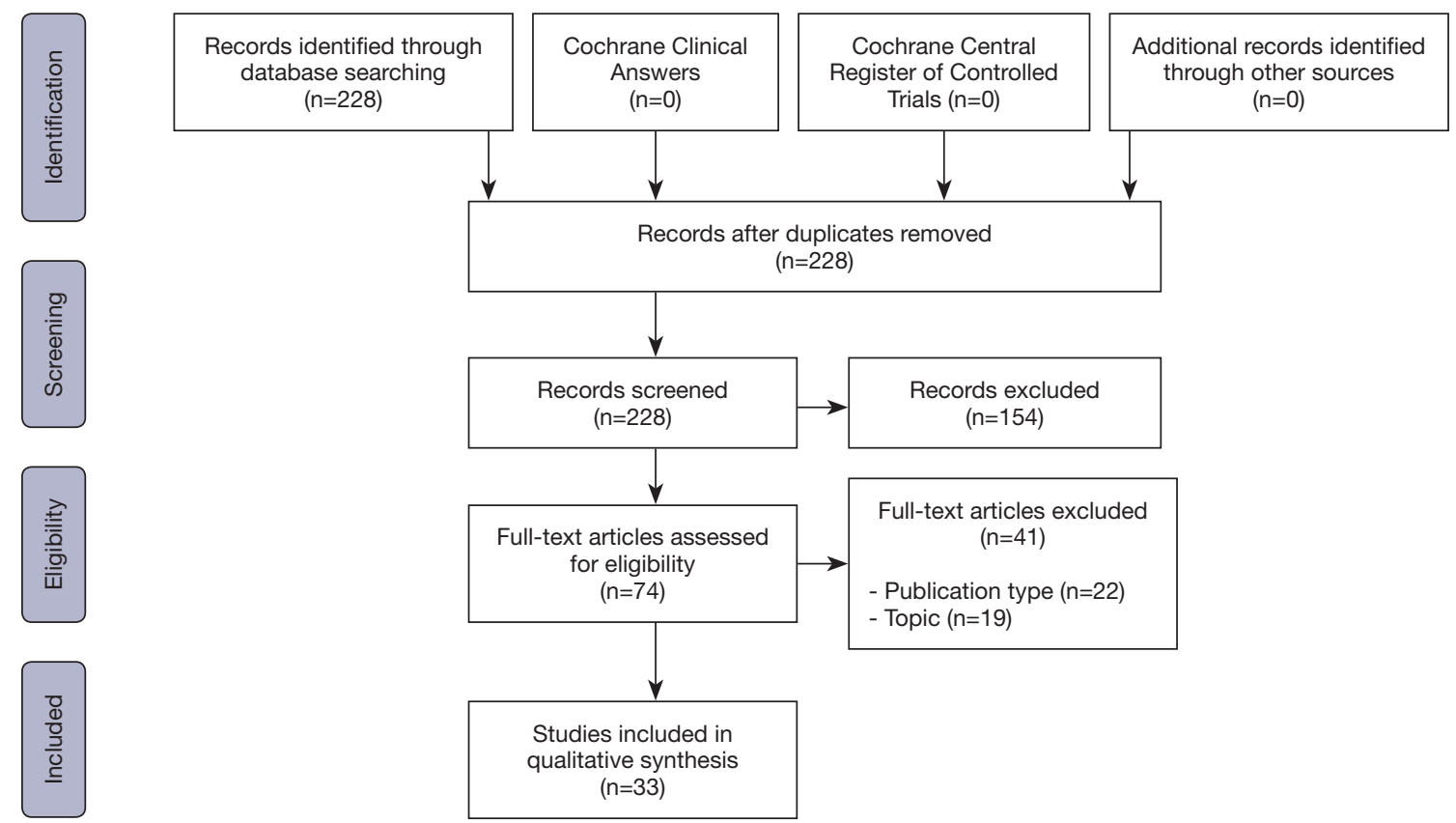

Figure 1 Preferred Reporting Items for Systematic Reviews and Meta-Analyses (PRISMA) Diagram.

\section{Discussion}

Phalloplasty techniques are still evolving and there is no universal procedure that can be applied to every patient (1). Reconstruction of the phallus has demonstrated to be challenging, especially because of the absence of a substitute for urethral and erectile tissue (6). In this systematic review, we noted that a large variety of flaps for phallic shaft creation in transgender patients were reported, and authors proposed variation of techniques aiming to improve outcomes. The two most common flaps reported by authors were RFFF and ALT, which corresponds to what is primarily seen in clinical practice (3).

The first techniques proposed for phalloplasty used locoregional pedicled flaps. Orticochea (41) introduced pedicle flap phalloplasty in 1970s. The ALT is a flap harvest from the thigh that is known to be the second most common approach for phalloplasty after RFFF. The fact it can be performed as a pedicled flap is considered a surgical advantage (19). Nonetheless, Felici and Felici (19) reported 6 cases of microsurgical ALT flap in transgender patients. ALT is innervated by lateral femoral cutaneous nerve and is has good blood supply (42). It has a hidden donor scar, allows bigger phallus creation (longer and larger girth) and has enough rigidity for intercourse (3). However, it might not be a good fit for a tube-within-a-tube phalloplasty if subcutaneous tissue is greater than $1 \mathrm{~cm}$, and the location of its innervation on the top of the deep fascia predispose nerve damage during phalloplasty that can harm phallic sensation $(3,6)$.

Due to the establishment of microsurgical techniques, flaps from distant areas have become more feasible. Puckett, Reinisch, and Montie (43) introduced in the 1980s the free flap phalloplasty. The most common microsurgical flap performed in clinical practice is the radial forearm $(1,3)$. Although this flap is known to leave a socially stigmatizing scar, it has numerous advantages: great innervation from medial antebrachial cutaneous nerve, reliable vascularity, and thin tissue thickness allowing reconstruction of phallus and urethra. RFFF was the most common flap reported in the literature, present on 15 of 33 articles.

Two other microsurgical flaps for phalloplasty are the free fibula flap and latissimus dorsi flap. The free fibula flap is an attractive microsurgical flap due to its rigidity that allows sexual intercourse. Nonetheless, erosion is likely to occur and connecting fibula and pubic bone is problematic (1). Although not common in clinical practice, latissimus dorsi flaps are still in use. It is a large flap that promotes a hidden scar. The main disadvantages of this flap is the absence of innervation, and the fact it does not allow tube-within-a-tube approach to create penile urethra, necessary for urethra lengthening, and requires at least 
Table 1 Summary of the studies

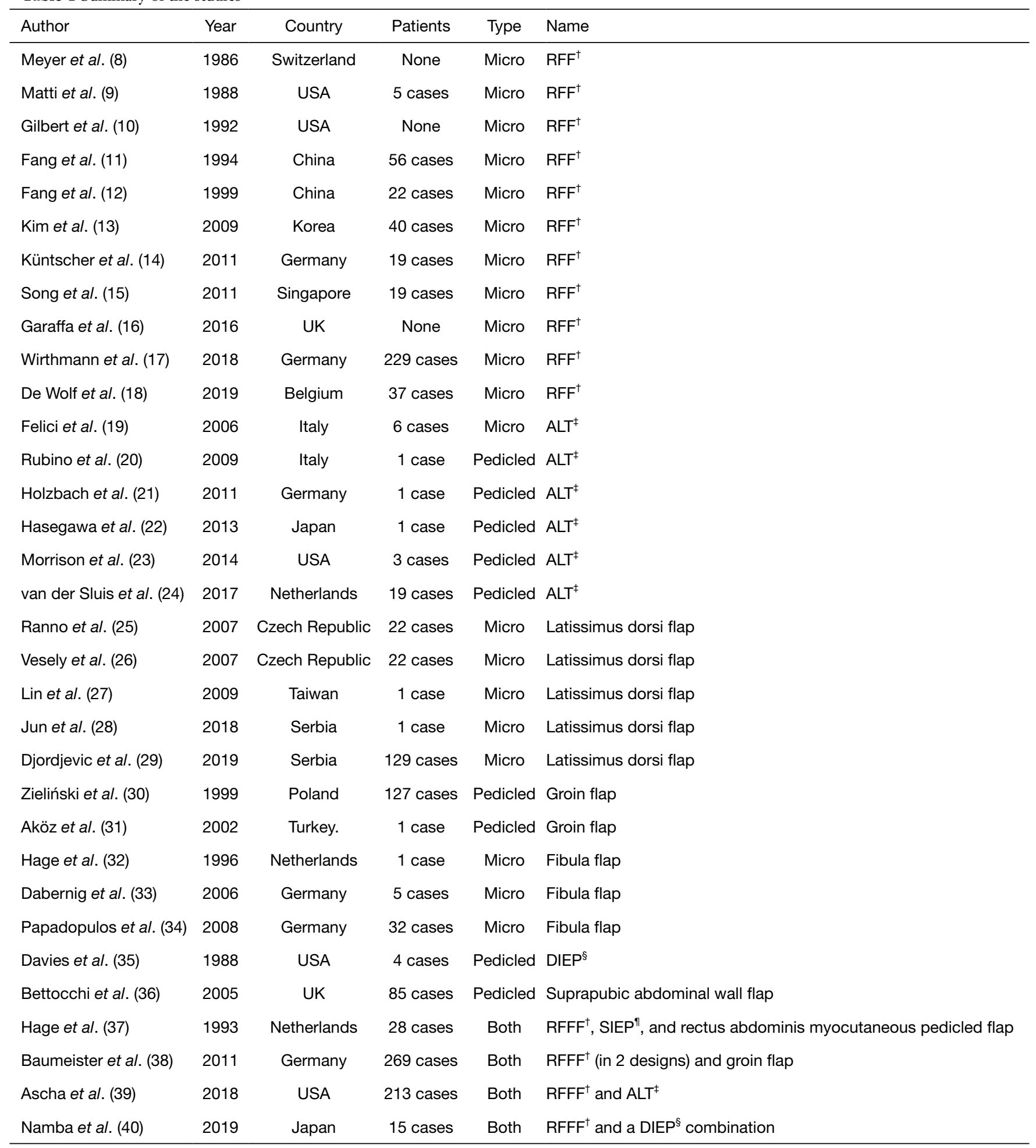

\footnotetext{
${ }^{\dagger}$, radial forearm free flap; ${ }^{\ddagger}$, anterolateral thigh; ${ }^{\S}$, deep inferior epigastric flap; ${ }^{\uparrow}$, superficial inferior epigastric flap.
} 
two-stage reconstructions (28). There have been reports of the "paradox erection" that allows patients to have sexual intercourse.

We acknowledge limitations in our study, frequent to systematic literature reviews, such as the potential bias in the analysis of the information collected in each article. We focused on studies reporting surgical flaps for phallic shaft creation in transgender patients, therefore we did not include phalloplasty techniques described for other groups of patients such as trauma that could potentially be employed on transgender patients. Nonetheless, we believe that our systematic review adds an overview of the scientific evidence about surgical techniques of phalloplasty in transgender patients.

\section{Conclusions}

The literature heterogenicity on surgical flaps for phallic shaft creation in transgender patients reflects how challenging reconstruction of the phallus is. Currently, there is no universal procedure that could be applied to every patient. Therefore, the surgical approach must be chosen considering surgeon experience, physical examination, and patient desire. The reported flaps in order of most commonly found in the literature were: radial forearm free flap, anterolateral thigh flap, latissimus dorsi free flap, abdominal flap, fibular free flap, and groin flap. We hope this review supports future studies on surgical flaps for phallic shaft creation in transgender patients.

\section{Acknowledgments}

Funding: This work was supported by the Mayo Clinic Center for Individualized Medicine and Center for Regenerative Medicine; and the Plastic Surgery Foundation.

\section{Footnote}

Provenance and Peer Review: This article was commissioned by the editorial office, Annals of Translational Medicine, for the series "Transgender Surgery". The article has undergone external peer review.

Reporting Checklist: The authors have completed the PRISMA reporting checklist. Available at http://dx.doi. org/10.21037/atm-20-3527

Conflicts of Interest: All authors have completed the ICMJE uniform disclosure form (available at http://dx.doi. org/10.21037/atm-20-3527). The series "Transgender Surgery" was commissioned by the editorial office without any funding or sponsorship. XL served as the unpaid Guest Editor of the series. The authors have no other conflicts of interest to declare.

Ethical Statement: The authors are accountable for all aspects of the work in ensuring that questions related to the accuracy or integrity of any part of the work are appropriately investigated and resolved.

Open Access Statement: This is an Open Access article distributed in accordance with the Creative Commons Attribution-NonCommercial-NoDerivs 4.0 International License (CC BY-NC-ND 4.0), which permits the noncommercial replication and distribution of the article with the strict proviso that no changes or edits are made and the original work is properly cited (including links to both the formal publication through the relevant DOI and the license). See: https://creativecommons.org/licenses/by-nc-nd/4.0/.

\section{References}

1. Schechter LS, Safa B. Introduction to Phalloplasty. Clin Plast Surg 2018;45:387-9.

2. Byne W, Bradley SJ, Coleman E, et al. Report of the American Psychiatric Association Task Force on Treatment of Gender Identity Disorder. Arch Sex Behav 2012;41:759-96.

3. Morrison SD, Shakir A, Vyas KS, et al. Phalloplasty: A Review of Techniques and Outcomes. Plast Reconstr Surg 2016;138:594-615.

4. Monstrey S, Hoebeke P, Selvaggi G, et al. Penile reconstruction: is the radial forearm flap really the standard technique? Plast Reconstr Surg 2009;124:510-8.

5. Selvaggi $G$, Bellringer J. Gender reassignment surgery: an overview. Nat Rev Urol 2011;8:274-82.

6. Monstrey SJ, Ceulemans P, Hoebeke P. Sex Reassignment Surgery in the Female-to-Male Transsexual. Semin Plast Surg 2011;25:229-44.

7. De Cuypere G, T'Sjoen G, Beerten R, et al. Sexual and physical health after sex reassignment surgery. Arch Sex Behav 2005;34:679-90.

8. Meyer R, Daverio PJ, Dequesne J. One-stage phalloplasty in transsexuals. Ann Plast Surg 1986;16:472-9.

9. Matti BA, Matthews RN, Davies DM. Phalloplasty using the free radial forearm flap. Br J Plast Surg 1988;41:160-4. 
10. Gilbert DA, Jordan GH, Devine CJ, Jr., et al. Microsurgical forearm "cricket bat-transformer" phalloplasty. Plast Reconstr Surg 1992;90:711-6.

11. Fang RH, Lin JT, Ma S. Phalloplasty for female transsexuals with sensate free forearm flap. Microsurgery 1994;15:349-52.

12. Fang RH, Kao YS, Ma S, et al. Phalloplasty in female-tomale transsexuals using free radial osteocutaneous flap: a series of 22 cases. Br J Plast Surg 1999;52:217-22.

13. Kim SK, Lee KC, Kwon YS, et al. Phalloplasty using radial forearm osteocutaneous free flaps in femaleto-male transsexuals. J Plast Reconstr Aesthet Surg 2009;62:309-17.

14. Küntscher MV, Hartmann B. The radial forearm phalloplasty with prelaminated urethra: a report of our learning curve during the last 6 years. Handchir Mikrochir Plast Chir 2011;43:222-6.

15. Song C, Wong M, Wong CH, et al. Modifications of the radial forearm flap phalloplasty for female-to-male gender reassignment. J Reconstr Microsurg 2011;27:115-20.

16. Garaffa G, Ralph DJ. Free Flap Phalloplasty For Female To Male Gender Dysphoria. J Sex Med 2016;13:1942-7.

17. Wirthmann AE, Majenka P, Kaufmann MC, et al. Phalloplasty in Female-to-Male Transsexuals by Gottlieb and Levine's Free Radial Forearm Flap Technique-A Long-Term Single-Center Experience Over More than Two Decades. J Reconstr Microsurg 2018;34:235-41.

18. De Wolf E, Claes K, Sommeling CE, et al. Free Bipedicled Radial Forearm and Posterior Interosseous Artery Perforator Flap Phalloplasty. J Sex Med 2019;16:1111-7.

19. Felici N, Felici A. A new phalloplasty technique: the free anterolateral thigh flap phalloplasty. J Plast Reconstr Aesthet Surg 2006;59:153-7.

20. Rubino C, Figus A, Dessy LA, et al. Innervated island pedicled anterolateral thigh flap for neo-phallic reconstruction in female-to-male transsexuals. J Plast Reconstr Aesthet Surg 2009;62:e45-9.

21. Holzbach T, Giunta RE, Machens HG, et al. [Phalloplasty with pedicled anterolateral thigh flap ("ALT-Flap")]. Handchir Mikrochir Plast Chir 2011;43:227-31.

22. Hasegawa K, Namba Y, Kimata Y. Phalloplasty with an innervated island pedicled anterolateral thigh flap in a female-to-male transsexual. Acta Med Okayama 2013;67:325-31.

23. Morrison SD, Son J, Song J, et al. Modification of the tube-in-tube pedicled anterolateral thigh flap for total phalloplasty: the mushroom flap. Ann Plast Surg 2014;72
Suppl 1:S22-6.

24. van der Sluis WB, Smit JM, Pigot GLS, et al. Double flap phalloplasty in transgender men: Surgical technique and outcome of pedicled anterolateral thigh flap phalloplasty combined with radial forearm free flap urethral reconstruction. Microsurgery 2017;37:917-23.

25. Ranno R, Vesely J, Hyza P, et al. Neo-phalloplasty with reinnervated latissimus dorsi free flap: a functional study of a novel technique. Acta Chir Plast 2007;49:3-7.

26. Vesely J, Hyza P, Ranno R, et al. New technique of total phalloplasty with reinnervated latissimus dorsi myocutaneous free flap in female-to-male transsexuals. Ann Plast Surg 2007;58:544-50.

27. Lin CT, Chen LW. Using a free thoracodorsal artery perforator flap for phallic reconstruction--a report of surgical technique. J Plast Reconstr Aesthet Surg 2009;62:402-8.

28. Jun MS, Pusica S, Kojovic V, et al. Total Phalloplasty With Latissimus Dorsi Musculocutaneous Flap in Female-to-male Transgender Surgery. Urology 2018;120:269-70.

29. Djordjevic ML, Bencic M, Kojovic V, et al. Musculocutaneous latissimus dorsi flap for phalloplasty in female to male gender affirmation surgery. World J Urol 2019;37:631-7.

30. Zieliński T. Phalloplasty using a lateral groin flap in female-to-male transsexuals. Acta Chir Plast 1999;41:15-9.

31. Aköz T, Kargi E. Phalloplasty in a female-to-male transsexual using a double-pedicle composite groin flap. Ann Plast Surg 2002;48:423-7; discussion 427.

32. Hage JJ, Winters HA, Van Lieshout J. Fibula free flap phalloplasty: modifications and recommendations. Microsurgery 1996;17:358-65.

33. Dabernig J, Chan LK, Schaff J. Phalloplasty with free (septocutaneous) fibular flap sine fibula. J Urol 2006;176:2085-8.

34. Papadopulos NA, Schaff J, Biemer E. The use of free prelaminated and sensate osteofasciocutaneous fibular flap in phalloplasty. Injury 2008;39 Suppl 3:S62-7.

35. Davies DM, Matti BA. A method of phalloplasty using the deep inferior epigastric flap. Br J Plast Surg 1988;41:165-8.

36. Bettocchi C, Ralph DJ, Pryor JP. Pedicled pubic phalloplasty in females with gender dysphoria. BJU Int 2005;95:120-4.

37. Hage JJ, Bouman FG, de Graaf FH, et al. Construction of the neophallus in female-to-male transsexuals: the Amsterdam experience. J Urol 1993;149:1463-8. 
38. Baumeister S, Sohn M, Domke C, et al. Phalloplasty in female-to-male transsexuals: experience from 259 cases. Handchir Mikrochir Plast Chir 2011;43:215-21.

39. Ascha M, Massie JP, Morrison SD, et al. Outcomes of Single Stage Phalloplasty by Pedicled Anterolateral Thigh Flap versus Radial Forearm Free Flap in Gender Confirming Surgery. J Urol 2018;199:206-14.

40. Namba Y, Watanabe T, Kimata Y. Flap Combination Phalloplasty in Female-to-Male Transsexuals. J Sex Med
2019;16:934-41.

41. Orticochea M. A new method of total reconstruction of the penis. Br J Plast Surg 1972;25:347-66.

42. Wei FC, Jain V, Celik N, et al. Have we found an ideal soft-tissue flap? An experience with 672 anterolateral thigh flaps. Plast Reconstr Surg 2002;109:2219-26; discussion 2227-30.

43. Puckett CL, Reinisch JF, Montie JE. Free flap phalloplasty. J Urol 1982;128:294-7.
Cite this article as: Boczar D, Huayllani MT, Saleem HY, Cinotto G, Avila FR, Kassis S, Lu X, Rinker BD, Forte AJ. Surgical techniques of phalloplasty in transgender patients: a systematic review. Ann Transl Med 2021;9(7):607. doi: 10.21037/atm-20-3527 